\title{
РАСПРОСТРАНЕННЫЕ ПРОБЛЕМЫ ПРИ ОБУЧЕНИИ ВОКАЛУ НА НАЧАЛЬНОМ ЭТАПЕ
}

\author{
А. Н. Ренева \\ (Московский гуманитарный университет)
}

Аннотация: В статье отмечаются наиболее распространенные проблемы при обучении вокалу молодежь: зажатый звук, неумение смешивать регистры и пр. В обучении пению, считает автор, очень важна этапность развития техники.

Ключевые слова: вокал; преподавание вокала; пение

\section{COMMON PROBLEMS AT EARLY STAGES OF TEACHING SINGING}

\author{
A. N. Renyova \\ (Moscow University for the Humanities)
}

\begin{abstract}
The article examines the most widespread problems that arise in teaching singing to youth audiences: stiff vocal, inability to mix registers, etc. We argue that mastering vocal stage by stage is crucial in teaching singing.

Keywords: vocal; teaching singing; singing
\end{abstract}

В наше время слушателям доступна самая разнообразная музыка. Не секрет, что молодое поколение в наши дни увлекается современной «западной» музыкой. И небезосновательно. Вокалисты и вокалистки мировой эстрады, как правило, имеют сильные голоса с большим диапазоном, владеют мелизматикой, основами импровизации и т. д. Это, безусловно, симпатизирует слушателям, а также стимулирует начинающих исполнителей брать в работу технически сложные для исполнения мировые шлягеры. Проблема заключается в том, что руководители вокальных студий и преподаватели музыкальных школ не всегда объясняют своим подопечным, что для исполнения этих произведений просто необходимо владеть основами вокальной техники. В их числе: правильное дыхание, использование резонаторов при пении, пение «в маску», владение микстом смешанным регистром и т. д. 
Наблюдая за юными вокалистами на различных профессиональных конкурсах, я все чаще прихожу к выводу, что последствием такого подхода к обучению является форсированное пение. Не пройдя определенные этапы в занятиях, юные певцы пытаются добиться результата другими средствами.

Вот самые распространенные ошибки.

Вместо плотного звука на форте, который достигается пением в резонаторы с использованием «зевка», мы видим зажатый, «крикливый» звук, сила которого обеспечивается сильным давлением на голосовой аппарат.

Отсюда происходит и неумение филировать звук, т. к. уйти на диминуэндо при таком способе звукоизвлечения не предоставляется возможным. Это также касается и наличия динамических оттенков.

Также одной из причин пережатого исполнения верхних нот является неумение смешивать регистры, т. е. петь микстом. Пытаясь «перетащить» насыщенное плотное звучание грудного регистра на высокие ноты, начинающий певец поднимает гортань, зажимая звук. Таким образом, ноты в верхнем регистре звучат плоско, тембрально не окрашенно. В этом случае замечается и склонность к занижению. В результате, мы видим, что страдает и интонация. Надо заметить, что проблема с интонацией - это не всегда проблема слуха, но очень часто проблема именно техники.

И, конечно, нельзя не остановиться на самом главном аспекте. Неправильное пение, постоянное форсирование звука неизбежно ведет к заболеванию голосовых связок. Как известно, вопрос восстановления голосового аппарата очень тонкий и деликатный. Привычки, выработанные годами, ликвидируются с большим трудом, т. к. существует мышечная память. Поэтому процесс восстановления может быть достаточно длительным. Особенно в группе риска оказываются детские неокрепшие голоса.

Итак, в обучении пению очень важна этапность развития: шаг за шагом, от простого к сложному. Форсированное пение - это результат безответственного отношения педагога к голосовому аппарату обучающегося, результат «перескакивания» через один или несколько этапов вокального развития, результат погони за внешней яркостью, эффектностью и пренебрежения качеством вокального исполнения.

Ренева Анна Николаевна - старший преподаватель кафедры культуры и искусства Московского гуманитарного университета. Адрес: 111395 , Россия, г. Москва, ул. Юности, д. 5. Тел.: +7 (499) 374-59-40. Эл. адрес: 3730014@mail.ru 
Renyova Anna Nikolaevna, Senior Lecturer, Department of Culture and Art, Moscow University for the Humanities. Postal address: 5 Yunosti St., Moscow, Russian Federation 111395. Tel.: +7 (499) 374-59-40. E-mail: 3730014@mail. $\mathrm{ru}$ 